ENTREPRENEURSHIP AND SUSTAINABILITY ISSUES

ISSN 2345-0282 (online) http://jssidoi.org/jesi/

2021 Volume 8 Number 4 (June)

http://doi.org/10.9770/jesi.2021.8.4(24)
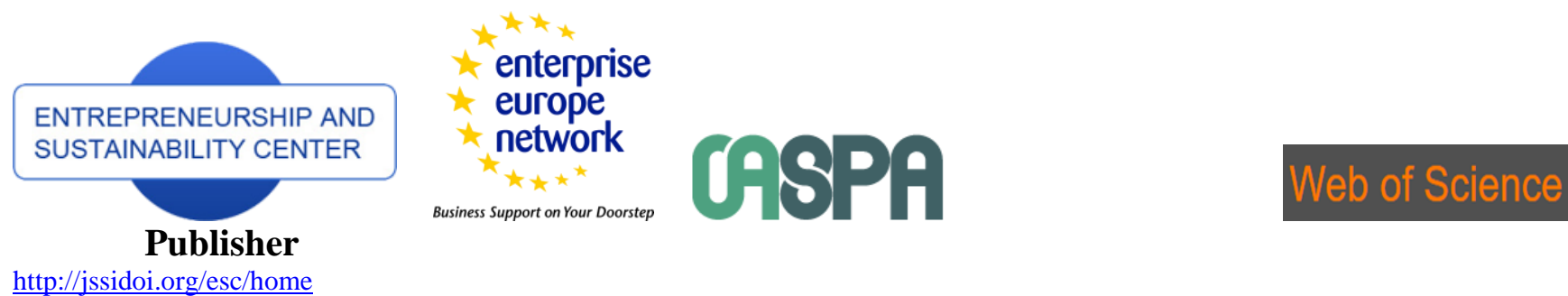

http://jssidoi.org/esc/home

1) Clarivate

Analytics

\title{
THE GENDER-BASED ATTAINMENT OF EDUCATION AND FEMALE ENTREPRENEURSHIP: THE EUROPEAN PERSPECTIVE
}

\author{
Aleksandra Gawel \\ Poznan University of Economics and Business, Al. Niepodleglosci 10, 61-875 Poznan, Poland \\ E-mail: aleksandra.gawel@ue.poznan.pl
}

Received 10 February 2021; accepted 15 April 2021; published 30 June 2021

\begin{abstract}
Although in European countries women obtain higher education more often than men, they still comprise about $30 \%$ of entrepreneurs. To understand the gender gap in entrepreneurship, the study aims to assess the impact of education on female entrepreneurship in two aspects, as explained by both male and female education levels and by different levels of education (primary, secondary, tertiary). To verify hypotheses, the empirical models are estimated with female entrepreneurship as the dependent variable and with the level of education as the independent one with the panel regression method for panel data for 31 European countries yearly 2000 2019. Results confirm that both male and female education levels impact female entrepreneurship. Female entrepreneurship is positively related to the share of females with higher and partial secondary education, as well as the share of males with primary education. Female entrepreneurship is reduced by the share of females with primary education and the share of males with higher education. There are two aspects of novelty in the paper. Firstly, female entrepreneurship is explained by both male and female education levels as both genders create the social environment for entrepreneurship; female education has a direct impact through the skills and competences, while male education impacts indirectly by influencing the business environment. The second aspect is the assumption that female entrepreneurship is explained by different levels of education (primary, secondary and tertiary), which impact their decisions to enter entrepreneurship.
\end{abstract}

Keywords: female entrepreneurship; female education levels; male education levels; European countries

Reference to this paper should be made as follows: Gawel, A. 2021. The Gender-Based Attainment of Education and Female Entrepreneurship: The European Perspective. Entrepreneurship and Sustainability Issues, 8(4), 403-417.

http://doi.org/10.9770/jesi.2021.8.4(24)

JEL Classifications: L26, J16

\section{Introduction}

In Europe, males are twice as likely as females to enter entrepreneurship (Dilli, Westerhuis 2018; Ester, Román 2017), despite increasing female participation in the workforce (Alsos et al. 2016). Women not only run their own businesses less often, but they also differ in terms of goals, size, profitability and growth intentions when compared to male entrepreneurs (Giotopoulos et al. 2017). The explanation of the gender gap in entrepreneurship is mostly done within institutional theory (i.e. Estrin, Mickiewicz 2011; Chowdhury, Audretsch 2014), 


\section{ENTREPRENEURSHIP AND SUSTAINABILITY ISSUES}

ISSN 2345-0282 (online) http://jssidoi.org/jesi/

2021 Volume 8 Number 4 (June)

http://doi.org/10.9770/jesi.2021.8.4(24)

psychological or personal treats (i.e. Lawter et al. 2016), generation explanations (Este, Román 2017) or human capital theories.

Education level is often seen as a factor supporting entrepreneurship (Westhead, Solesvik 2016). However, in the context of female entrepreneurship, on the one hand, some research shows that women's education is not the most important factor in becoming an entrepreneur and many entrepreneurs do not have a formal educational background for their businesses (Loh, Dahesihsari 2013; Anambane, Adom 2018). On the other hand, the lack of formal education is believed to be one of the factors explaining the gender gap in entrepreneurship (Vukmirović 2019; Chowdhury, Audretsch 2014; Ribes-Giner et al. 2019).

Although education is a multidimensional factor, in research on female entrepreneurship, it is seen mostly through the perspective of women's higher education. However, in the paper, it is assumed that female entrepreneurship can explained by both male and female education levels. The attitude of both genders creates the social environment for entrepreneurship; female education can have a direct impact on their entrepreneurship, thanks to skills and competences gained by formal education and work experience, while male education can have an indirect impact by shaping social norms and expectations, as well as standards for running a business. Moreover, it is assumed that female entrepreneurship is explained by different levels of education (primary, secondary and tertiary) - the knowledge and skills needed to run a business can be gained thanks to both formal education and work experience. Females with primary and secondary education could miss some competences from higher education; however, they gain other competences through their work experience.

The paper is organized as follows. The first part presents the theoretical background with a discussion of the gender gap in entrepreneurship, the role of education in shaping the decision to enter into entrepreneurship and the existing knowledge on the impact of education on female entrepreneurship. Based on this, the second part of the paper is methods and materials, including the development of the hypotheses and research method employed in the paper. Then, the results and discussion, as well as final conclusions, are presented.

\section{THEORETICAL BACKGROUND}

\subsection{The gender gap in entrepreneurship}

Gender equality has been raised in modern societies, thanks to increasing female participation in the workforce (Alsos et al. 2016); however, a gender gap in entrepreneurship is still observed. In Europe, males are twice as likely as females to enter into entrepreneurship (Ester, Román 2017). Women not only enter into entrepreneurship less often, but they also differ in terms of goals, size, profitability and growth intentions when compared to male entrepreneurs (Giotopoulos et al. 2017).

Various frameworks are used in the literature to explain the gender gap in entrepreneurship, mostly institutional theory with cultural and social explanations (Estrin, Mickiewicz 2011; Chowdhury, Audretsch 2014); psychological points of view, such as independency or flexibility as personal treats (Lawter et al. 2016); generation explanations (Ester, Román 2017); or human capital theories. Part of the research focuses on factors influencing female entrepreneurship which actually impact entrepreneurs regardless of gender, and tries to recognize the differences in female and male reactions to them. Such examples can be found among both necessity-driven factors, where female are motivated to enter into entrepreneurship by an unfavourable situation in the labour market, such as unemployment, frustration and a lack of professional development (McGowan et al. 2012, Cantú Cavada et al. 2017; Ng, Fu 2018); and among opportunity-driven factors, such as, for example independence, flexibility, job satisfaction (Holmen et al. 2011; Lawter et al. 2016), and better work-life balance (McGowan et al. 2012). On the other hand, there are also researches which concentrate only on women-specific factors; for example, norms for and stereotypes about females (Kobeissi 2010; Pérez-Pérez, Avilés-Hernández 2016). 


\section{ENTREPRENEURSHIP AND SUSTAINABILITY ISSUES}

ISSN 2345-0282 (online) http://jssidoi.org/jesi/

2021 Volume 8 Number 4 (June)

http://doi.org/10.9770/jesi.2021.8.4(24)

The institutional framework generally affects entrepreneurship by influencing the uncertainty and expected return on investment regardless of the gender (Chowdhury, Audretsch 2014). The informal institutions of norms, values, culture, and stereotypes are often listed as causes for the gender gap in entrepreneurship (Petrović, Radukić 2019; van Ewijk, Belghiti-Mahut 2019). The prototypical entrepreneur is perceived as masculine and individual; these features are male-stereotypes (Orser et al. 2011; Gimenez-Jimenez et al. 2020), while females are stereotypically perceived as caring and nurturing (Orser et al. 2011). Results showing that the fertility rate negatively impacts female entrepreneurship (Dutta, Mallick 2018) support this cultural impact.

The gender gap in entrepreneurship is also perceived as the result of gender inequality and discrimination against women (Estrin, Mickiewicz 2011; Berger, Kuckertz 2016) observed in the gender wage gaps (Ravazzini, Chesters 2018; Khoreva 2011), gender labour-force gap, the presence of women in positions of power (Ribes-Giner et al. 2018), human development (Maniyalath, Narendran 2016) or occupational female segregation (Damelang, Ebensperger 2020).

Education level is often seen as a factor supporting entrepreneurial activities (Westhead, Solesvik 2016), however mostly in the context of entrepreneurship education (Henry 2013; Henry, Lewis 2018), higher education (Solesvik 2013) or specifically entrepreneurship education among students (Iglesias-Sánchez et al. 2016). Although the gender gap in higher levels of educational achievement has been closing for over last 50 years, in the EU, women are more likely than men to have a high level of education, while they are still constitute only one third of entrepreneurs (Dilli, Westerhuis 2018). Comparing these facts shows that the relationship between education and female entrepreneurship is a more complex issue and requires deeper insights.

\subsection{Education as a factor shaping entrepreneurship as an occupational decision}

Education is a multidimensional factor, analysed not only by many scientific disciplines, but also within economics, by many kind of theories. The most influential theories regarding education as a factor shaping entrepreneurship as an occupational decision from the economic point of view are: human capital theory (education as investment, and knowledge, skills and competences as outcomes), occupational choice theory (education impacts labour market opportunities as well as entrepreneurial decisions) or institutional theory (education as the result of formal and informal institutions).

Research on the impact of human capital on entrepreneurship is vital and has been increasingly applied for over two decades (Marvel et al. 2016). Human capital is a very broad concept which refers to the knowledge, skills and competencies impacting individuals' productivity and their economic value (Marvel 2013) dividing it into general and specific human capital. The general human capital is equally effective across different contexts and situations while specific human capital is related to its usefulness in particular context (Marvel 2013; Capelleras et al. 2019). Education is one of the key drivers of the general human, and is assumed to impact entrepreneurial performance by providing discipline, motivation, self-confidence, skills and knowledge (Westhead, Solesvik 2016).

Another typology of human capital made by Marvel et al. (2016) distinguishes both its investments and outcomes. Investments in human capital are related to education, training/ experience, and investments in recruitment while outcomes are related to knowledge, skills and ability (Marvel et al. 2016). Due to data availability, human capital is the most often operationalised by its investment in formal education, measured by years of schooling or educational attainment (Faggian et al. 2017), instead of their outcomes, though cognitive, technical, problemsolving, social and managerial skills and abilities are related to entrepreneurial activity (Qian 2017), as well as education.

Formal education as a form of general human capital and entrepreneurial experience as a form of specific human capital are the most common factors considered to have an impact on entrepreneurship (Capelleras et al. 2019). 


\section{ENTREPRENEURSHIP AND SUSTAINABILITY ISSUES}

ISSN 2345-0282 (online) http://jssidoi.org/jesi/

2021 Volume 8 Number 4 (June)

http://doi.org/10.9770/jesi.2021.8.4(24)

Education is often used as a control variable in the research of determinants of entrepreneurship (Hamilton et al. 2019). Entrepreneurial education is also of special interest, as it is believed that it let to acquire the skills and competences needed to increase the quantity of entrepreneurs or their competences (Honig, Samuelsson 2012; Henry 2013; Henry, Lewis 2018).

Although investment in human capital is believed to reinforce entrepreneurial outcomes, the research results show that relationship between them is not inconclusive, as it is not straightforward. The only exception seems to be formal education, which is a statistically significant factor, though small in magnitude (Hogendoorn et al. 2019). Reasons for that might be related to the endogeneity of human capital, as both are related to favourable personal traits or the correct choice of education by future entrepreneurs (Hogendoorn et al. 2019).

The perspective of occupational choice theory assumes entrepreneurship to be a choice between two forms of activity: a wage employee with a predictable and risk-free salary, or an entrepreneur gaining risky entrepreneurial profit (Kihlstrom, Laffont 1979; Bradley 2016; Pardo, Ruiz-Tagle 2017). Determinants for becoming an entrepreneur can be grouped as social-demographic factors, economic factors and personal factors (i.e. Rupasingha, Goetz 2013; Fritsch et al. 2015; Simoes et al. 2016; Szarucki et al. 2016). In this context, education is a bit of a misleading factor. Research suggests a U-shape relationship between the educational attainment and entrepreneurship, as both the highest and the lowest categories of education level are related to high the entrepreneurship rate. It is connected with the bimodal patterns of entrepreneurial entry for individuals with high job-related human capital who create the best and most successful companies, and individuals with low jobrelated human capital who run independent businesses but not such lucrative ones (Ohyama 2015). Individuals with higher levels of education get better job market prospects, which increases the opportunity costs for entrepreneurship as an occupational choice and impacts the higher growth aspirations of entrepreneurial activities (Capelleras et al. 2019). Initially, access to increased levels of education can lead to the reduction of opportunity entrepreneurship, as it gives the necessary skills to gain a better paid job without the risk of entrepreneurship. However, later, greater levels of education and a rising emphasis on entrepreneurship education at universities makes entrepreneurship more desirable as a career path (Cullen et al. 2014). The relationship between education attainment and entrepreneurial growth aspirations is related to several aspects. Formal education helps individuals to better recognize entrepreneurial opportunities and to have better access to entrepreneurial resources (Capelleras et al. 2019). A higher level of education also impacts access to a better social network as the result of a longer stay in the education system (Capelleras et al. 2019). The educational attainment of entrepreneurs also impacts their growth intentions, regardless of the business cycle (Giotopoulos et al. 2017).

The impact of education on entrepreneurship can be also analysed from the point of view of institutional theory, which distinguishes between formal and informal institutions (Aparicio et al. 2019; Webb et al. 2020). Formal institutions include regulations, procedures, education, family context and differential income levels, while informal ones include networks, culture, values, and beliefs (Estrin, Mickiewicz 2011; Williams, Shahid 2016).

Although education is treated as a formal institution (Estrin, Mickiewicz 2011), informal institutions such as social norms or stereotypes also impact the gendered patterns of power, influencing career choices made by men and women in the field of education (Reichborn-Kjennerud, Svare 2014). The institutions affect men and women differently; the vocational training systems can even exacerbate gender inequality (Dilli, Westerhuis 2018). The educational system seems to reinforce and the same time limit the cultural values that support opportunity entrepreneurship (Cullen et al. 2014). 


\section{ENTREPRENEURSHIP AND SUSTAINABILITY ISSUES}

ISSN 2345-0282 (online) http://jssidoi.org/jesi/

2021 Volume 8 Number 4 (June)

http://doi.org/10.9770/jesi.2021.8.4(24)

\subsection{Education and female entrepreneurship}

The impact of education on female entrepreneurship is not clear. In developed countries, education gender gaps have narrowed, with slightly higher female educational attainment (Sung won et al. 2018); in the EU, women are more likely to reach higher education than men, while the gender gap in entrepreneurship still remains high (Dilli, Westerhuis 2018).

On one hand, some research results show that women's education is not the most important factor in becoming an entrepreneur and many entrepreneurs do not have a formal educational background for their businesses (Loh, Dahesihsari 2013). Even more, the cultural point of view suggests perceiving entrepreneurship as appropriate for uneducated women, while highly-educated women are pushed more towards formal employment (Anambane, Adom 2018). This relationship can be explained by the feminist approach to entrepreneurship, according to which knowledge, also gained in education, is created and reproduced by social conditions and positions, with gender being a social construct influencing behaviours, values and beliefs (Loh, Dahesihsari 2013). In the UK, although women have been more likely to enter university than men since the early 1990s, female students still face negative stereotypes and lowered expectations from faculty because of their gender as well as greater challenges in relation to post-degree life chances (Woodfield 2019). Female human capital can be shaped by gender-role stereotypes related to gender-related tasks and gender identification with masculine or feminine characteristics, which leads to the gendering of human capital (Westhead, Solesvik 2016).

On the other hand, the lack of formal education is believed to be one of the factor explaining the gender gap in entrepreneurship (Vukmirović 2019), as research shows the positive impact of education level on female entrepreneurship during times of crisis (Aparicio et al. 2019). Female entrepreneurship is affected by their higher level of education (Chowdhury, Audretsch 2014; Ribes-Giner et al. 2019). Formal education accumulating explicit knowledge seems to be particularly important for female entrepreneurs, as it helps them gain access to certain labour markets and social networks. Thanks to the access to the labour market, female entrepreneurs can increase their tacit knowledge related to general business skills (Chowdhury, Audretsch 2014). Education is also a factor which moderates the negative impact of the fertility rate on female entrepreneurship, as higher levels of female education can reduce this impact (Dutta, Mallick 2018).

As education is one of the factors influencing the occupational choice between paid employment and entrepreneurship, female education should be considered in a wider context. Education is a factor, which influences the development of flexible gender identities, and flexibility in career choices shapes individuals' ability to move between male-dominated and female-dominated occupations (Sung won et al. 2018). However, greater female educational attainment does not always affect better labour outcomes (Dilli, Westerhuis 2018). Occupational gender segregation is observed worldwide, as typical female-coded jobs are lower paid and give fewer career opportunities (Damelang, Ebensperger 2020). Labour market segmentation theory explains it by dividing the labour market made by gender, formal education, geographic regions, or race into two parts: the primary and secondary labour markets (Mora, Muro 2015). Men tend to concentrate in primary sectors, characterised by higher productivity and higher wages, while women concentrate in the secondary ones, being less productive and less profitable, with lower wages (Karamessini, Ioakimoglou 2007; Aidis, Weeks 2016; Symeonaki, Filopoulou 2017).

Education might be a factor in changing that segmentation. Female education in fields linked to high-growth industries is perceived as a factor which might mitigate the gender gap in entrepreneurship (Sullivan, Meek 2012). According to research results among Chinese youth, education leads to work flexibility, within which men were more likely to prefer typically masculine jobs, while women were more open to both masculine and feminine jobs (Sung won et al. 2018). In the UK, graduates of both genders are equally likely to secure paid, full-time employment within six months after graduation, but men are also more likely to report being unemployed at this point (Woodfield 2019). 


\section{ENTREPRENEURSHIP AND SUSTAINABILITY ISSUES}

ISSN 2345-0282 (online) http://jssidoi.org/jesi/

2021 Volume 8 Number 4 (June)

http://doi.org/10.9770/jesi.2021.8.4(24)

Deeper understanding of the relationship looks at not just education attainment as a whole, but also some specific areas of education. The gender gap connected with female participation in STEM education (science, technology, engineering, or mathematics) negatively impacts not only total female entrepreneurial activity, but also women's entrepreneurial engagement in knowledge-intensive sectors and their high-growth aspirations (Dilli, Westerhuis 2018). Also, significant gender differences of entrepreneurial attitude are recognized among scientists as the prior record of researchers' patenting and institutional leadership influences male researchers' openness to entrepreneurship, but not female ones (Goel et al. 2015).

\section{METHODS AND MATERIALS}

\subsection{General assumption and research hypotheses}

Although, as shown in the literature review, the impact of education on female entrepreneurship is multidimensional, so far, most research associates education with higher education or years in education in the context both of general human capital (Faggian et al. 2017) and of entrepreneurship (Hamilton et al. 2019). Another attitude is to focus on the impact of entrepreneurial education (Westhead, Solesvik 2016).

Education is part of informal institutions (Estrin, Mickiewicz 2011), but is also influenced by gender social norms or stereotypes influencing career choices (Reichborn-Kjennerud, Svare 2014; Pinho 2017). This being the case, it is not just the female level of education which should be analysed, but also male education attainment. It is assumed in the paper that male education could be a factor which shapes the social environment supporting or discouraging females from entering into entrepreneurship, which led to the formulation of hypothesis 1.

H1. Female entrepreneurship is shaped by both male and female education levels, and the direct impact of female education and indirect impact of male education

To get a clearer picture of the impact of education on female entrepreneurship, the analyses of different levels of education are proposed in the paper, not just higher education, but also primary and secondary education. Considering female primary education, it is hypothesised in the paper that because of the lack of female skills and competences, the higher the share of females with primary education, the lower the level of female entrepreneurship (hypothesis 2.1). On the other hand, a relatively high level of primary education among males contributes to a higher level of female entrepreneurship, as it lowers social pressure against female entrepreneurship. Males with lower level of education are more open to professionally active women, including entrepreneurial activity, as females make important financial contributions to family incomes and males do not have enough skills and competences to create a social barrier for female entry to entrepreneurship (hypothesis 2.2).

H2.1. A higher share of females with primary education impacts lower female entrepreneurship

H2.2. A higher share of male primary education impacts higher female entrepreneurship

The opposite relationship is assumed when considering the impact of female and male secondary and higher education on women's entrepreneurship. Thanks to getting a better education, females are able to acquire more of the skills and competences needed to run a business, as well as build better social networks and gain access to finances, which lead to their higher level of entrepreneurial entry (hypotheses 3.1 and 4.1). Contrary, a higher share of males with secondary and tertiary education creates stronger social pressure against entrepreneurial women and reduces female entrepreneurship. Males with better education get their human capital developed enough to obtain a successful professional career and by that, on the one hand, expect women to concentrate more on family duties than on contributing to family finances with female entrepreneurial activity. On the other hand, 
the more successful males are thanks to their higher competences, the more they also create a competitive entry barrier for women (hypotheses 3.2 and 4.2).

H3.1. A higher share of females with secondary education impacts a higher female entrepreneurship rate H3.2. A higher share of male secondary education impacts a lower female entrepreneurship rate

H4.1. A higher share of females with tertiary education impacts a higher female entrepreneurship rate H4.2. The higher the share of male tertiary education, the lower female entrepreneurship

\subsection{Research assumptions}

To verify hypotheses, empirical research was conducted to estimate the econometric models, with female entrepreneurship as the dependent variable and with the level of education as the independent one. European countries were selected for the research, as they represent similar levels of institutional environment and cultural background. Based on annual data from the Eurostat database for the years 2000-2019 for 31 countries, the panel of 620 data was created. Details on analysed countries are presented in tab. 1.

The female entrepreneurship rate as a dependent variable is calculated as the share of females self-employed in total self-employment for a population aged 15 to 64 years. On average, over a 20 year period, the female entrepreneurship rate in selected European countries was 30,75, meaning that women were 30,75\% of entrepreneurs. Comparing the average rates of female entrepreneurship in the analysed countries (tab. 1), significant differences among countries can be observed. The average female entrepreneurship rates differ from $16,79 \%$ in Malta to 39,65\% in Portugal. Female entrepreneurship rates are lower than the European average in the case of 18 countries and higher than the European average in the case of 13 countries.

Table 1. Country's average female entrepreneurship rates (FE) in years 2000-2019

\begin{tabular}{|c|c|c|c|}
\hline \multicolumn{2}{|c|}{ FE LOWER THAN SAMPLE AVERAGE (30.75) } & \multicolumn{2}{|c|}{ FE HIGHER THAN SAMPLE AVERAGE (30.75) } \\
\hline Country & FE average & Country & FE average \\
\hline Malta & 16.79 & Portugal & 39.65 \\
\hline Ireland & 20.08 & Latvia & 38.66 \\
\hline Denmark & 26.31 & Lithuania & 38.12 \\
\hline Sweden & 26.94 & Switzerland & 36.04 \\
\hline Slovakia & 26.97 & Croatia & 35.30 \\
\hline Romania & 27.64 & Luxembourg & 35.26 \\
\hline Slovenia & 27.98 & Austria & 34.86 \\
\hline Czechia & 28.66 & Netherlands & 34.17 \\
\hline Italy & 28.66 & Poland & 34.05 \\
\hline Cyprus & 28.70 & Bulgaria & 33.63 \\
\hline Norway & 28.79 & Finland & 32.62 \\
\hline Greece & 29.24 & Hungary & 32.25 \\
\hline Iceland & 29.55 & Germany & 31.50 \\
\hline United Kingdom & 29.72 & & \\
\hline France & 29.87 & & \\
\hline Estonia & 30.44 & & \\
\hline Belgium & 30.62 & & \\
\hline Spain & 30.62 & & \\
\hline
\end{tabular}




\section{ENTREPRENEURSHIP AND SUSTAINABILITY ISSUES}

ISSN 2345-0282 (online) http://jssidoi.org/jesi/

2021 Volume 8 Number 4 (June)

http://doi.org/10.9770/jesi.2021.8.4(24)

Independent variables reflect the level of education for men and women, measured as the share of males and females with primary, secondary and tertiary education attainment in the total population. Two control variables are also implemented in the estimations: the female unemployment rate and the share of females inactive because of family and caring responsibilities in the total population. All independent and control variables relate to persons aged 15-64 years, similarly to the dependent variable. Raw data were converted into a natural logarithm to linearize the relationships. Definitions and abbreviations of all variables are presented in tab. 2 .

Table 2. List of variables and their abbraviations

\begin{tabular}{|l|l|l|}
\hline Variable & Abb. & Operationalization \\
\hline Female entrepreneurship & $\operatorname{lnFE}$ & $\begin{array}{l}\text { Female entrepreneurship rate being the share of female entrepreneurs (\%) in total } \\
\text { entrepreneurs converted into natural logarithms }\end{array}$ \\
\hline $\begin{array}{l}\text { Females with primary } \\
\text { education }\end{array}$ & $\operatorname{lnFP}$ & $\begin{array}{l}\text { Female primary education being the share of females with primary education (\%) in total } \\
\text { population converted into natural logarithms }\end{array}$ \\
\hline $\begin{array}{l}\text { Males with primary } \\
\text { education }\end{array}$ & $\operatorname{lnMP}$ & $\begin{array}{l}\text { Male primary education being the share of males with primary education (\%) in total } \\
\text { population converted into natural logarithms }\end{array}$ \\
\hline $\begin{array}{l}\text { Females with secondary } \\
\text { education }\end{array}$ & $\operatorname{lnFS}$ & $\begin{array}{l}\text { Female secondary education being the share of females with secondary education (\%) in } \\
\text { total population converted into natural logarithms }\end{array}$ \\
\hline $\begin{array}{l}\text { Males with secondary } \\
\text { education }\end{array}$ & $\operatorname{lnMS}$ & $\begin{array}{l}\text { Male secondary education being the share of males with secondary education }(\%) \text { in total } \\
\text { population converted into natural logarithms }\end{array}$ \\
\hline $\begin{array}{l}\text { Females with tertiary } \\
\text { education }\end{array}$ & $\operatorname{lnFT}$ & $\begin{array}{l}\text { Female higher education being the share of females with tertiary education (\%) in total } \\
\text { population converted into natural logarithms }\end{array}$ \\
\hline $\begin{array}{l}\text { Males with tertiary } \\
\text { education }\end{array}$ & $\begin{array}{l}\text { Male higher education being the share of males with tertiary education (\%) in total } \\
\text { population converted into natural logarithms }\end{array}$ \\
\hline Female inactivity & $\begin{array}{l}\text { Female inactivity rate being the share of females inactive because of family and caring } \\
\text { responsibilities }(\%) \text { in total population converted into natural logarithms }\end{array}$ \\
\hline Female unemployment & $\operatorname{lnFU}$ & $\begin{array}{l}\text { Female unemployment rate being the share of unemployed females }(\%) \text { in female } \\
\text { population converted into natural logarithms }\end{array}$ \\
\hline
\end{tabular}

Source: own elaboration.

As in terms of female entrepreneurship significant differences are observed in European countries, despite the institutional and cultural convergence of European countries, the hypotheses verification is done based on the whole group of countries and separately for the groups of countries with relatively low and relatively high female entrepreneurship according to the values presented in Tab. 1.

With the use of panel regression models, three sets of regression functions are estimated:

- with primary education level for females and males as independent variables in whole group of 31 European countries (Reg.1), in countries with relatively low (Reg.4) and relatively high (Reg.5) female entrepreneurship;

- with a secondary level of education for both genders as independent variables in whole group of 31 European countries (Reg.2), in countries with relatively low (Reg.6) and relatively high (Reg.7) female entrepreneurship;

- with a tertiary level of education for women and men as independent variables in whole group of 31 European countries (Reg.3), in countries with relatively low (Reg.8) and relatively high (Reg.9) female entrepreneurship.

In all 3 sets of regression functions, both the share of inactive females because of family duties and female unemployment rates as control variables are implemented.

The calculation of the variance inflation factors (VIF) is the next step (tab. 3), to detect collinearity. In most cases Reg.1, Reg.3, Reg.4, Reg.5, Reg.8 and Reg.9 collinearity problems are not encountered, since all of the variables 


\section{ENTREPRENEURSHIP AND SUSTAINABILITY ISSUES}

ISSN 2345-0282 (online) http://jssidoi.org/jesi/

2021 Volume 8 Number 4 (June)

http://doi.org/10.9770/jesi.2021.8.4(24)

reported VIF values significantly below 10. In the case of Reg.2, Reg.6 and Reg.7, the share of males with secondary education is collinear according to VIF values, which is why this variable is excluded from the next steps. After doing so, VIFs values do not indicate any problem with collinearity.

Table 3. VIFs collinearity tests with FE as dependent variable

\begin{tabular}{|c|c|c|c|c|c|c|c|c|c|c|c|}
\hline Variables & $\begin{array}{l}\text { VIFs } \\
\text { Reg.1 }\end{array}$ & $\begin{array}{l}\text { VIFs } \\
\text { Reg.4 }\end{array}$ & $\begin{array}{l}\text { VIFs } \\
\text { Reg.5 }\end{array}$ & Variables & $\begin{array}{l}\text { VIFs } \\
\text { Reg.2 }\end{array}$ & $\begin{array}{l}\text { VIFs } \\
\text { Reg.6 }\end{array}$ & $\begin{array}{l}\text { VIFs } \\
\text { Reg.7 }\end{array}$ & Variables & $\begin{array}{l}\text { VIFs } \\
\text { Reg.3 }\end{array}$ & $\begin{array}{l}\text { VIFs } \\
\text { Reg.8 }\end{array}$ & $\begin{array}{l}\text { VIFs } \\
\text { Reg.9 }\end{array}$ \\
\hline $\operatorname{lnMP}$ & 6.165 & 7.217 & 5.882 & $\operatorname{lnMS}$ & $\mathrm{X}$ & $\mathrm{X}$ & $\mathrm{X}$ & InMT & 3.660 & 9.653 & 2.623 \\
\hline $\operatorname{lnFP}$ & 6.284 & 7.399 & 6.303 & InFS & 1.002 & 1.018 & 1.006 & $\ln F T$ & 3.738 & 9.945 & 2.620 \\
\hline InFIR & 1.136 & 1.192 & 1.469 & InFIR & 1.042 & 1.146 & 1.089 & InFIR & 1.255 & 1.289 & 1.633 \\
\hline $\ln F U$ & 1.072 & 1.138 & 1.120 & $\ln F U$ & 1.042 & 1.135 & 1.087 & $\ln \mathrm{FU}$ & 1.220 & 1.148 & 1.665 \\
\hline
\end{tabular}

To determine the kind of panel regression, the Breuch-Pagan and Hausman tests were conducted (tab. 4). Statistics of Breuch-Pagan test indicate whether oridinary least squares or panel regression method should be used. As all statistics get a low p-value $(<0.05)$, it means the correctness of panel regression implementation. The Hausman test allows for estimating the nature of the observed effect in panel data between fixed and random effects. A low p-value $(<0.05)$ for the Hausman test suggests using the model with the fixed effects. As in all regression cases (tab. 4), the p-values of the Hausman test are much higher than 0.05, and the panel regression with random effects is the best method for estimation of Reg.1, Reg.2, Reg.3, Reg.4, Reg.5, Reg.6, Reg.7 and Reg.8 and fixed effects for Reg.9.

Table 4. Breusch-Pagan and Hausman test results with FE as dependent variable

\begin{tabular}{|l|l|l|l|l|l|l|l|l|l|l|}
\hline \multicolumn{2}{|c|}{ Tests } & Reg.1 & Reg.2 & Reg.3 & Reg.4 & Reg.5 & Reg.6 & Reg.7 & Reg.8 & Reg.9 \\
\hline $\begin{array}{l}\text { Statistics of } \\
\text { Breusch-Pagan test }\end{array}$ & LM & 3784.79 & 3345.96 & 4008.94 & 1636.51 & 604.758 & 1213.62 & 640.397 & 1877.76 & 712.881 \\
\cline { 2 - 11 } & $\mathrm{p}$ & 0 & 0 & 0 & 0 & 0 & 0 & 0 & 0 \\
\hline $\begin{array}{l}\text { Statistics of } \\
\text { Hausman test }\end{array}$ & $\mathrm{H}$ & 3.603 & 0.698 & 4.3798 & 6.978 & 5.185 & 1.385 & 4.202 & 2.654 & 9.900 \\
& $\mathrm{p}$ & 0.463 & 0.874 & 0.3570 & 0.137 & 0.269 & 0.709 & 0.241 & 0.617 & 0.042 \\
\hline
\end{tabular}

Source: own elaboration.

\section{RESULTS AND DISCUSSION}

The results of estimating regression function parameters based on panel regression with fixed and random effects are presented in tab. 5. Regarding primary education (Reg.1), the share of males with primary education impacts female entrepreneurship positively, while the share of women with primary education impacts negatively, meaning a higher share of males with primary education and a lower share of females with primary education influences a higher level of female entrepreneurship. It gives support for hypotheses H.2.1 and H.2.2. When secondary education is considered (Reg.2), the share of males with secondary education is not implemented as an independent variable because of collinearity (tab. 3), making hypothesis 3.2 impossible to verify. However the share of females with secondary education positively impacts female entrepreneurship, meaning that a higher level of secondary education among women influences their higher entrepreneurial activity. It gives support for hypothesis 3.1. The last regression function (Reg.3) refers to higher education, and it shows that the share of males with higher education negatively impacts female entrepreneurship, while the share of women with higher education impacts positively. These results support hypotheses 4.1 and 4.2, which assume that higher female entrepreneurship is shaped by a higher share of females with tertiary education and a lower share of males with tertiary education. All the results of regression functions also support hypothesis 1 , which assumed that female entrepreneurship is shaped by both male and female education levels. 
ENTREPRENEURSHIP AND SUSTAINABILITY ISSUES

ISSN 2345-0282 (online) http://jssidoi.org/jesi/

2021 Volume 8 Number 4 (June)

http://doi.org/10.9770/jesi.2021.8.4(24)

Table 5. Regression functions parameters with $\mathrm{FE}$ as dependent variable

\begin{tabular}{|c|c|c|c|}
\hline Variables & Full sample of countries & Countries with low FE & Countries with high FE \\
\hline \multicolumn{4}{|c|}{ Models with primary education } \\
\hline & Reg.1 & Reg.4 & Reg.5 \\
\hline Const & $\begin{array}{c}3.832 * * * \\
(0.081)\end{array}$ & $\begin{array}{l}4.240 * * * \\
(0.113)\end{array}$ & $\begin{array}{c}3.622 * * * \\
(0.077)\end{array}$ \\
\hline $\operatorname{lnMP}$ & $\begin{array}{c}0.195 * * * \\
(0.072)\end{array}$ & $\begin{array}{c}0.050 \\
(0.088)\end{array}$ & $\begin{array}{l}0.241 * * * \\
(0.082)\end{array}$ \\
\hline $\operatorname{lnFP}$ & $\begin{array}{c}-0.397 * * * \\
(0.055)\end{array}$ & $\begin{array}{c}-0.429 * * * \\
(0.066)\end{array}$ & $\begin{array}{c}-0.223 * * * \\
(0.067)\end{array}$ \\
\hline $\operatorname{lnFIR}$ & $\begin{array}{c}-0.017^{* *} \\
(0.008)\end{array}$ & $\begin{array}{c}-0.031 * * * \\
(0.009) \\
\end{array}$ & $\begin{array}{c}-0.071 * * * \\
(0.016) \\
\end{array}$ \\
\hline $\operatorname{lnFU}$ & $\begin{array}{c}0.069 * * * \\
(0.011)\end{array}$ & $\begin{array}{c}0.063 * * * \\
(0.015)\end{array}$ & $\begin{array}{c}0.018 \\
(0.012)\end{array}$ \\
\hline Fit statistics & $\begin{array}{l}\text { 'Between' variance }=0.033 \\
\text { 'Within' variance }=0.006\end{array}$ & $\begin{array}{l}\text { 'Between' variance }=0.25 \\
\text { 'Within' variance }=0.007\end{array}$ & $\begin{array}{c}\text { 'Between' variance }=0.006 \\
\text { 'Within' variance }=0.003\end{array}$ \\
\hline \multicolumn{4}{|c|}{ Models with secondary education } \\
\hline & Reg.2 & Reg.6 & Reg.7 \\
\hline const & $\begin{array}{l}3.073 * * * \\
(<0.0001)\end{array}$ & $\begin{array}{l}2.494 * * * \\
(0.159)\end{array}$ & $\begin{array}{l}4.274 * * * \\
(0.112)\end{array}$ \\
\hline $\operatorname{lnFS}$ & $\begin{array}{l}0.097 * * * \\
(0.007)\end{array}$ & $\begin{array}{l}0.235^{* * * *} \\
(0.049)\end{array}$ & $\begin{array}{c}-0.177 * * * \\
(0.034)\end{array}$ \\
\hline $\operatorname{lnFIR}$ & $\begin{array}{c}-0.024 * * * \\
(0.006)\end{array}$ & $\begin{array}{l}-0.012 \\
(0.011)\end{array}$ & $\begin{array}{c}-0.093^{* * * *} \\
(0.013)\end{array}$ \\
\hline $\operatorname{lnFU}$ & $\begin{array}{c}0.0421 * * * \\
(0.001)\end{array}$ & $\begin{array}{c}0.064 * * * \\
(0.019)\end{array}$ & $\begin{array}{c}0.013 \\
(0.011)\end{array}$ \\
\hline Fit statistics & $\begin{array}{l}\text { 'Between' variance }=0.032 \\
\text { 'Within' variance }=0.009\end{array}$ & $\begin{array}{l}\text { 'Between' variance }=0.023 \\
\text { 'Within' variance }=0.011\end{array}$ & $\begin{array}{c}\text { 'Between' variance }=0.005 \\
\text { 'Within' variance }=0.003\end{array}$ \\
\hline \multicolumn{4}{|c|}{ Models with tertiary education } \\
\hline & Reg.3 & Reg.8 & Reg.9 \\
\hline Const & $\begin{array}{l}3.005 * * * \\
(0.061)\end{array}$ & $\begin{array}{l}2.556^{* * * *} \\
(0.087)\end{array}$ & $\begin{array}{l}3.752 * * * \\
(0.075)\end{array}$ \\
\hline $\operatorname{lnMT}$ & $\begin{array}{c}-0.333 * * * \\
(0.057)\end{array}$ & $\begin{array}{c}-0.177^{*} \\
(0.095)\end{array}$ & $\begin{array}{c}-0.320 * * * \\
(0.058)\end{array}$ \\
\hline $\operatorname{lnFT}$ & $\begin{array}{c}0.435 * * * \\
(0.042)\end{array}$ & $\begin{array}{c}0.414 * * * \\
(0.068)\end{array}$ & $\begin{array}{l}0.271 * * * \\
(0.048)\end{array}$ \\
\hline $\operatorname{lnFIR}$ & $\begin{array}{c}0.001 \\
(0.007)\end{array}$ & $\begin{array}{l}-0.006 \\
(0.008)\end{array}$ & $\begin{array}{c}-0.069 * * * \\
(0.016)\end{array}$ \\
\hline $\operatorname{lnFU}$ & $\begin{array}{c}0.051 * * * \\
(0.010)\end{array}$ & $\begin{array}{c}0.071^{* * *} \\
(0.014)\end{array}$ & $\begin{array}{c}0.007 \\
(0.011)\end{array}$ \\
\hline Fit statistics & $\begin{array}{l}\text { 'Between' variance }=0.035 \\
\text { 'Within' variance }=0.006\end{array}$ & $\begin{array}{l}\text { 'Between' variance }=0.027 \\
\text { 'Within' variance }=0.006\end{array}$ & $\begin{array}{l}\text { LSDV R }^{2}=0.68 \\
\text { Within } R^{2}=0.30\end{array}$ \\
\hline
\end{tabular}

The results of estimating regression function parameters separately for groups of countries with lower and higher than average levels of female entrepreneurship mostly are in line with results for all countries (see tab. 5). Results give significant support for hypotheses $\mathrm{H} 2.1, \mathrm{H} 4.1$ and $\mathrm{H} 4.2$ as the share of females with primary education negatively impacts (Reg.4 and Reg.5), the share of females with higher education positively impacts and the share of males with higher education negatively impacts (Reg.8) and (Reg.9) female entrepreneurship in both group of countries. Hypothesis 2.2 gets some support, as the share of males with primary education impacts female entrepreneurship positively in the case of countries with high female entrepreneurship (Reg.5), but this variable is statistically insignificant in the case of countries with low female entrepreneurship (Reg.4). 


\section{ENTREPRENEURSHIP AND SUSTAINABILITY ISSUES}

ISSN 2345-0282 (online) http://jssidoi.org/jesi/

2021 Volume 8 Number 4 (June)

http://doi.org/10.9770/jesi.2021.8.4(24)

The differences in determinants between countries with high and low female entrepreneurship can be observed when secondary education is considered. It is the same for the whole group of European countries; also, for both sub-groups, the share of males with secondary education is not implemented as an independent variable because of collinearity (tab. 3), which means that hypothesis 3.2 could not get support. Contrarily, the impact of the share of women with secondary education depends on the country's level of female entrepreneurship. In countries with a lower than average level of female entrepreneurship, the share of females with secondary education influences female entrepreneurship positively, while in countries with higher than average level, it affects it negatively, which does not support hypothesis 3.1.

Looking through all the results, hypothesis 1, assuming that female entrepreneurship is impacted by both male and female education levels, got support. In both the group of all countries and separately for countries with different levels of female entrepreneurship, shares of males with primary and higher education impact female entrepreneurship, as does the share of females with all three educational attainments. The only factor impossible to verify is the share of males with secondary education because of its collinearity with other variables and due to this, its exclusion from the regression functions.

The next aspect worthy of notice is that when comparing the absolute values of regression function parameters, female entrepreneurship rates seem to be more sensitive to the level of female education in countries with a relatively lower level of female entrepreneurship.

\section{CONCLUSIONS}

The gender gap in entrepreneurship is still an unexplained phenomenon, with the level of education as one of its causes. However, although in European countries, women obtain higher education more often than men, they are half as likely to enter into entrepreneurship. Education is a multidimensional factor shaping occupational decisions, being explained by human capital theory (education, which impacts knowledge and skills), institutional theory (education as the result of formal and informal institutions) or occupational choice theory (education impacts labour market opportunities as well as entrepreneurial decisions).

In earlier research, education as a factor influencing female entrepreneurship is mostly considered in the context of the share of females with higher education, or it is treated as a control variable. Moreover, female education is mostly analysed without regard for lower levels of education and out of context of male education.

There are two aspects in the research which constitute novelty. First is the assumption that female entrepreneurship is explained by both male and female education levels. Both genders create the social environment for entrepreneurship; female education has a direct impact through the skills and competences gained by formal education and work experience, while male education impacts indirectly by influencing the social norms and expectations or standards for running a business. The second aspect is the assumption that female entrepreneurship is explained by different levels of education (primary, secondary and tertiary), which impact their decisions to enter entrepreneurship.

Using the panel regression method, with panel data for 31 European countries for the years 2000-2019, hypothesis $\mathrm{H} 1$ on the impact of both male and female education levels on female entrepreneurship gets support. The most clear relationship picture is connected with females' primary and higher education and with males' higher education. Results for the whole sample of countries and for both sub-samples with higher and lower than average levels of female entrepreneurship indicate that the share of females with primary education (hypothesis H2.1) and the share of males with higher education (hypothesis H4.2) negatively impacts female entrepreneurship, while the share of females with higher education impacts positively (hypothesis H4.1). The share of males with primary education reduces the gender gap in entrepreneurship, positively influencing female entrepreneurship (hypothesis 


\section{ENTREPRENEURSHIP AND SUSTAINABILITY ISSUES}

ISSN 2345-0282 (online) http://jssidoi.org/jesi/

2021 Volume 8 Number 4 (June)

http://doi.org/10.9770/jesi.2021.8.4(24)

H2.2) in the whole group of countries and in sub-group with a higher level of female entrepreneurship, while this factor is not statistically significant in the case of countries with a lower level of female education.

The most unclear results are related to the impact of secondary education on female entrepreneurship. In the panel of all countries and in the sub-panel of countries with a low level of female entrepreneurship, the share of females with secondary education positively influences women's entrepreneurship (hypothesis H3.1); however, for the sub-panel of countries with a higher level of female entrepreneurship, this relationship is the opposite. On the other hand, the impact of the share of males with secondary education on female entrepreneurship (hypothesis H3.2) is impossible to analyse because of the collinearity of this variable with other variables in the model, thus excluding it from estimations.

The results of the research have some implications for shaping policies reducing the gender gap. To raise the level of female entrepreneurship, increasing the share of women with higher education is important, but so is the reduction of primary education by encouraging females to continue their education. As one of the factors limiting female entrepreneurship is the share of males with higher education, it seems important to raise the societal aspect of the gender gap by increasing male openness towards and awareness of female entrepreneurial activity.

Research has also its limitiation related to availability and nature of panel data. Research was limited to European countries showing relationships at macro level, not at a level of particular country or at personal level.

\section{References}

Aidis, R., \& Weeks, J. (2016). Mapping the gendered ecosystem. The evolution of measurement tools for comparative high-impact female entrepreneur development. International Journal of Gender and Entrepreneurship, 8 (4), 330-352. https://doi.org/10.1108/IJGE-12-2015$\underline{0044}$

Alsos, G.A., Ljunggren, E., Carter, S. \& Jørstad, M.O. (2016). Women, Family and Entrepreneurship: Strategies For Managing Work-Life Balance Challenges. Academy of Management Annual Meeting Proceedings. https://doi.org/10.5465/ambpp.2016.16079abstract

Anambane, G., \& Adom, K. (2018). Assessing the Role of Culture in Female Entrepreneurship in Contemporary Sub-Saharan Society: Insights From The Nabadam District of Ghana. Journal of Developmental Entrepreneurship, 23 (3). http://dx.doi.org/10.1142/S1084946718500176

Aparicio, S., Urbano, D., Audretsch, D., and Noguera, M. (2019). Female and male entrepreneurship during the economic crisis: an institutional tale of European countries. Revista de Economia Mundial, 51, pp. 163-184.

Berger, E.S.C., \& Kuckertz, A. (2016). Female entrepreneurship in startup ecosystems worldwide. Journal of Business Research, 69, 51635168. https://doi.org/10.1016/j.jbusres.2016.04.098

Bradley, J. (2016). Self-employment in an equilibrium model of the labor market. IZA Journal of Labor Economics, 5 (6), https://doi.org/10.1186/s40172-016-0046-8

Cantú Cavada, M., Bobek, V., \& Maček, A. (2017). Motivation Factors for Female Entrepreneurship in Mexico. Entrepreneurial Business and Economics Review, 5 (3), 133-148. http://doi.org/10.15678/EBER.2017.050307

Capelleras, J.-L., Contin-Pilart, I., Larraza-Kintana, M., \& Martin-Sanchez, V. (2019). Entrepreneurs' human capital and growth aspirations: the moderating role of regional entrepreneurial culture. Small Business Economics, 52, 3-25. https://doi.org/10.1007/s11187$\underline{017-9985-0}$

Chowdhury, F., \& Audretsch, D.B. (2014). Institution as looting apparatus: impact of gender equality and institutions on female entrepreneurship. Eurasian Business Review, 4, 207-225. http://doi.org/10.1007/s40821-014-0008-7

Cullen, J.B., Johnson, J.L., \& Parboteeah, K.P. (2014). National Rates of Opportunity Entrepreneurship Activity: Insights from Institutional Anomie Theory. Entrepreneurship Theory and Practice, 38 (4), 775-806. http://doi.org/10.1111/etap.12018 


\section{ENTREPRENEURSHIP AND SUSTAINABILITY ISSUES}

ISSN 2345-0282 (online) http://jssidoi.org/jesi/

2021 Volume 8 Number 4 (June)

http://doi.org/10.9770/jesi.2021.8.4(24)

Damelang A., \& Ebensperger, S. (2020). Gender composition of occupations and occupational characteristics: Explaining their true relationship by using longitudinal data. Social Science Research, 86, 102394. https://doi.org/10.1016/j.ssresearch.2019.102394

Dilli, S. \& Westerhuis,G. (2018). How institutions and gender differences in education shape entrepreneurial activity: a cross-national perspective. Small Business Economics, 51, 371-392. https://doi.org/10.1007/s11187-018-0004-x

Dutta, N. \& Mallick, S. (2018). Enabling Women Entrepreneurs: Exploring Factors That Mitigate the Negative Impact of Fertility Rates on Female Entrepreneurship. KYKLOS, 71 (3), 402-432. https://doi.org/10.1111/kykl.12175

Ester, P., \& Román, A. (2017). A Generational Approach to Female Entrepreneurship in Europe. Journal of Women's Entrepreneurship and Education, 3-4, 1-27.

Estrin, S., \& Mickiewicz, T. (2011). Institutions and female entrepreneurship. Small Business Economics, 37, $397-415$. https://doi.org/10.1007/s11187-011-9373-0

Ewijk van, A.R., \& Belghiti-Mahut, S. (2019). Context, gender and entrepreneurial intentions. How entrepreneurship education changes the equation. International Journal of Gender and Entrepreneurship, 11 (1), 75-98. https://doi.org/10.1108/IJGE-05-2018-0054

Faggian, A., Partridge, M., \& Malecki, E.J. (2017). Creating an Environment for Economic Growth: Creativity, Entrepreneurship or Human Capital? International Journal of Urban and Regional Research, 41 (6), 997-1009. http://doi.org/10.1111/1468-2427.12555

Fritsch, M., Kritikos, A.S., \& Sorgner, A. (2015). Why did self-employment increase so strongly in Germany?. Entrepreneurship \& Regional Development, 27 (5-6), 307-333. https://doi.org/10.1080/08985626.2015.1048310

Gimenez-Jimenez, D., Calabrò, A., \& Urbano, D. (2020). The neglected role of formal and informal institutions in women's entrepreneurship: a multi-level analysis. Journal of International Entrepreneurship. https://doi.org/10.1007/s10843-020-00270-8

Giotopoulos, I., Kontolaimou, A., \& Tsakanikas, A. (2017). Drivers of high-quality entrepreneurship: what changes did the crisis bring about? Small Business Economics, 48, 913-930. http://doi.org/10.1007/s11187-016-9814-x

Goel, R.K., Goktepe-Hulten, D., \& Ram, R. (2015). Academics' entrepreneurship propensities and gender differences. Journal of Technology Transfer, 40, 161-177. http://doi.org/10.1007/s10961-014-9372-9

Hamilton, B.H., Papageorge, N.W., \& Pande, N. (2019).The right stuff? Personality and entrepreneurship. Quantitative Economics, 10, 643-691. https://doi.org/10.3982/QE748

Henry, C. (2013). Entrepreneurship education in HE: are policy makers expecting too much? Education + Training, 55 (8/9), 836-848, https://doi.org/10.1108/ET-06-2013-0079

Henry, C. \& Lewis, K. (2018) A review of entrepreneurship education research. Exploring the contribution of the Education + Training special issues, Education + Training, 60 (3), 263-286, https://doi.org/10.1108/ET-12-2017-0189

Hogendoorn, B., Rud, I., Groot, W., \& Maassen van den Brink, H. (2019), The Effects of Human Capital Interventions on Entrepreneurial Performance in Industrialized Countries. Journal of Economic Surveys, 33 (3), 798-826. http://doi.org/10.1111/joes.12308

Holmen, M., Min, T.T., \& Saarelainen E. (2011). Female Entrepreneurship in Afghanistan. Journal of Developmental Entrepreneurship, 16 (3), 307-331. http://dx.doi.org/10.1142/S1084946711001860

Honig, B., \& Samuelsson, M. (2012), Planning and the Entrepreneurs: A Longitudinal Examination of Nascent Entrepreneurs in Sweden. Journal of Small Business Management, 50 (3), 365-388.

Iglesias-Sánchez, P.P., Jambrino-Maldonado, C., Velasco, A.P. \& Kokash, H. (2016), Impact of entrepreneurship programmes on university students, Education + Training, 58 (2), 209-228, https://doi.org/10.1108/ET-01-2015-0004

Karamessini, M., \& Ioakimoglou, E. (2007). Wage determination and the gender pay gap: A feminist political economy analysis and decomposition, Feminist Economics, 13 (1), 31-66, https://doi.org/10.1080/13545700601075088

Khoreva, V. (2011). Gender pay gap and its Perceptions. Equality Diversity and Inclusion: An International Journal, 30 (3), $233-248$. https://doi.org/10.1108/02610151111124969 


\section{ENTREPRENEURSHIP AND SUSTAINABILITY ISSUES}

ISSN 2345-0282 (online) http://jssidoi.org/jesi/

2021 Volume 8 Number 4 (June)

http://doi.org/10.9770/jesi.2021.8.4(24)

Kihlstrom, R.E., \& Laffont, J.-J. (1979). A General Equilibrium Entrepreneurial Theory of Firm Formation Based on Risk Aversion. Journal of Political Economy, 87 (4), 719 - 748. https://doi.org/10.1086/260790

Kobeissi, N. (2010). Gender factors and female entrepreneurship: International evidence and policy implications. Journal of International Entrepreneurship, 8, 1-35. https://doi.org/10.1007/s10843-010-0045-y

Lawter, L., Rua, T., \& Andreassi, J. (2016). The Glass Cage: The Gender Pay Gap and Self-Employment in the United States. New England Journal of Entrepreneurship, 19 (1), 23-38.

Loh, J. M. I., \& Dahesihsari, R. (2013). Resilience and Economic Empowerment: A Qualitative Investigation of Entrepreneurial Indonesian Women. Journal of Enterprising Culture, 21 (1), 107-121. https://doi.org/10.1142/S0218495813500052

Maniyalath, N., \& Narendran, R. (2016). The human development index predicts female entrepreneurship rates. International Journal of Entrepreneurial Behavior \& Research, 22 (5), 745-766. https://doi.org/10.1108/IJEBR-11-2015-0258

Marvel, M.R. (2013). Human Capital and Search-Based Discovery: A Study of High-Tech Entrepreneurship, Entrepreneurship: Theory and Practice, 37 (2), 403-419. https://doi.org/10.1111/j.1540-6520.2011.00465.x

Marvel, M.R., Davis, J.L, \& Sproul, C.R. (2016). Human Capital and Entrepreneurship Research: A Critical Review and Future Directions. Entrepreneurship Theory and Practice, 40 (3), 599-626. https://doi.org/10.1111/etap.12136

McGowan, P., Lewis Redeker, C., Cooper, S.Y., \& Greenan, K. (2012). Female entrepreneurship and the management of business and domestic roles: Motivations, expectations and realities, Entrepreneurship \& Regional Development, 24 (1-2), 53-72,

https://doi.org/10.1080/08985626.2012.637351

Mora, J.J. \& Muro, J. (2015) Labor market segmentation in a developing country. The Indian Journal of Labour Economics, 58, 477-486. https://doi.org/10.1007/s41027-016-0024-5

Ng, K.S., \& Fu, P.P. (2018). Factors Driving Foreign Women Entrepreneurship in China. Entrepreneurial Business and Economics Review, 6 (4), 49-69. https://doi.org/10.15678/EBER.2018.060403

Ohyama, A. (2015). Entrepreneurship and Job-relatedness of Human Capital. Economica, 82, 740-768. https://doi.org/10.1111/ecca.12144

Orser, B. J., Elliott, C., \& Leck, J. (2011). Feminist attributes and entrepreneurial identity. Gender in Management: An International Journal, 26 (8), 561-589. https://doi.org/10.1108/17542411111183884

Pardo, C., \& Ruiz-Tagle, J. (2017). The dynamic role of specific experience in the selection of self-employment versus wage-employment. Oxford Economic Papers, 69 (1), 189-212. https://doi.org/10.1093/oep/gpw047

Pérez-Pérez, C. \& Avilés-Hernández, M. (2016). Explanatory factors of female entrepreneurship and limiting elements. SUMA DE NEGOCIOS, 7, 25-31. http://dx.doi.org/10.1016/j.sumneg.2015.12.004

Petrović, J., \& Radukić, S. (2019). An Analysis of the Development of Entrepreneurship in the Republic of Serbia with a Special Focus on Female Entrepreneurship. Journal of Women's Entrepreneurship and Education, 1-2, 1-16. https://doi.org/10.28934/jwee19.12

Pinho, J.C. (2017). Institutional theory and global entrepreneurship: exploring differences between factor- versus innovation-driven countries. Journal of International Entrepreneurship, 15, 56-84. https://doi.org/10.1007/s10843-016-0193-9

Qian, H. (2017). Skills and knowledge-based entrepreneurship: evidence from US cities. Regional Studies, 1 (10), $1469-1482$. https://doi.org/10.1080/00343404.2016.1213383

Ravazzini, L. \& Chesters, J. (2018). Inequality and Wealth: Comparing the Gender Wealth Gap in Switzerland and Australia. Feminist Economics, 24 (4), 83-107. https://doi.org/10.1080/13545701.2018.1458202

Reichborn-Kjennerud, Kristin \& Helge Svare. (2014). Entrepreneurial growth strategies: the female touch. International Journal of Gender and Entrepreneurship, 6 (2), 181-199. https://doi.org/10.1108/IJGE-04-2013-0043

Ribes-Giner, G., Moya-Clemente, I., Cervello-Royo, R., \& Perello-Marin, M.R. (2019). Wellbeing indicators affecting female entrepreneurship in OECD countries. Quality \& Quantity, 53, 915-933. https://doi.org/10.1007/s11135-018-0796-4 


\title{
ENTREPRENEURSHIP AND SUSTAINABILITY ISSUES
}

ISSN 2345-0282 (online) http://jssidoi.org/jesi/

2021 Volume 8 Number 4 (June)

http://doi.org/10.9770/jesi.2021.8.4(24)

Ribes-Giner, G., Moya-Clemente, I., Cervelló-Royo, R., \& Perello-Marin, M.R. (2018). Domestic economic and social conditions empowering female entrepreneurship. Journal of Business Research, 89, 182-189. https://doi.org/10.1016/j.jbusres.2017.12.005

Rupasingha, A., \& Goetz, S.J. (2013), Self-employment and local economic performance: Evidence from US counties, Papers in Regional Science, 92 (1), 141-162. https://doi.org/10.1111/j.1435-5957.2011.00396.x

Simoes, N., Crespo, N., \& Moreira, S.B. (2016). Individual Determinants of Self-Employment Entry: What Do We Really Know?. Journal of Economic Survey, 30 (4), 783-806. https://doi.org/10.1111/joes.12111

Solesvik, M.Z. (2013), Entrepreneurial motivations and intentions: investigating the role of education major, Education + Training, 55 (3), 253-271, https://doi.org/10.1108/00400911311309314

Sullivan, D. M., \& Meek, W. R. (2012). Gender and entrepreneurship: A review and process model. Journal of Managerial Psychology, 27 (5), 428-458. https://doi.org/10.1108/02683941211235373

Sung won, K., Brown, K.-E., \& Fong, V. L. (2018). How flexible gender identities give young women advantages in China's new economy, Gender and Education, 30 (8), 982-1000, https://doi.org/10.1080/09540253.2016.1274380

Symeonaki, M., \& Filopoulou, C. (2017). Quantifying gender distances in education, occupation and employment. Equality Diversity and Inclusion: An International Journal, 36 (4), 340-361. https://doi.org/10.1108/EDI-11-2016-0106

Szarucki, M., Brzozowski, J., \& Stankevičienè, J. (2016). Determinants of Self-Employment Among Polish and Romanian Immigrants in Germany. Journal of Business Economics and Management, 17 (4), 598-612, https://doi.org/10.3846/16111699.2016.1202313

Vukmirović, V. (2019). Entrepreneurship Education among University Students as a Predictor of Female Entrepreneurial Undertakings, Journal of Women's Entrepreneurship and Education, 3-4, 86-102. https://doi.org/10.28934/jwee19.34.pp86-102

Webb, J.W., Khoury, T.A., \& Hitt, M.A. (2020). The Influence of Formal and Informal Institutional Voids on Entrepreneurship. Entrepreneurship Theory and Practice, 44 (3), 504-526. https://doi.org/10.1177/1042258719830310

Westhead, P., \& Solesvik, M.Z. (2016). Entrepreneurship education and entrepreneurial intention: Do female students benefit? International Small Business Journal, 34 (8), 979-1003. https://doi.org/10.1177/0266242615612534

Williams, C.C., \& Shahid, M.S. (2016). Informal entrepreneurship and institutional theory: explaining the varying degrees of (in)formalization of entrepreneurs in Pakistan. Entrepreneurship \& Regional Development, 28 (1-2), 1-25. http://dx.doi.org/10.1080/08985626.2014.963889

Woodfield, R. (2019). The gendered landscape of UK higher education: do men feel disadvantaged? Gender and Education, 31 (1), $15-32$. https://doi.org/10.1080/09540253.2017.1288859

\begin{abstract}
Aleksandra GAWEL is a Professor of Economics at the Poznan University of Economics and Business in Poland. She received her Ph.D. in 1997, habilitation (post-doc degree) in 2008 and professorship of economic science from the President of Poland in 2015. She is the author or co-author of publications on entrepreneurship, entrepreneurial education, innovation, the business cycle, the labour market, and regional development. Her current research is focused on the sustainable aspects of entrepreneurship, mostly in the context of social and gender equality.
\end{abstract}

ORCID ID: 0000-0002-7426-3474

Copyright (C) 2021 by author(s) and VsI Entrepreneurship and Sustainability Center

This work is licensed under the Creative Commons Attribution International License (CC BY).

http://creativecommons.org/licenses/by/4.0/

c. (i) Open Access 